\title{
Hepatitis C Virus Antibody Positive
}

National Cancer Institute

\section{Source}

National Cancer Institute. Hepatitis C Virus Antibody Positive. NCI Thesaurus. Code

C160411.

An indication that antibodies that recognize the hepatitis $C$ virus have been detected in a sample. 